\title{
Yeşil renkli gölgeleme ağlarının bazı radyometrik özellikleri ve ortam mikrokliması ile bitki gelişimi üzerine etkisi
}

\section{Some radiometric properties of green coloured shade nettings and its effect on ambient microclimate and plant growth}

\author{
Nefise Yasemin TEZCAN \\ Akdeniz Üniversitesi, Ziraat Fakültesi, Tarımsal Yapılar ve Sulama Bölümü \\ Sorumlu yazar (Corresponding author): N. Y. Tezcan, e-posta (e-mail): nytezcan@akdeniz.edu.tr
}

\section{MAKALE BILLGISİ}

Alınış tarihi 31 Ağustos 2018

Düzeltilme tarihi 21 Kasım 2018

Kabul tarihi 21 Kasım 2018

\section{Anahtar Kelimeler:}

Iş̧1k seçici ağlar

Toplam ıșınım

PAR

Sicaklık

Domates

\begin{abstract}
ÖZ
Bu çalışma, Antalya'da Akdeniz Üniversitesi Ziraat Fakültesi Araştırma ve Uygulama Çiftliğinde açık tarla $\left(756 \mathrm{~m}^{2}\right)$ koşullarında yürütülmüştür. Denemede gölgeleme materyali olarak \% 40, \% 55, \% 75 ve \% 95 gölgeleme oranlı 4 farklı yeşil ışık seçici ağ kullanılmıştır. Araşıtırmada, ışık seçici ağların bazı radyometrik özellikleri (toplam ışııım ve fotosentetik etkin ışınım (PAR)) belirlenmiştir. Çalışmada ağların ortam mikroklimasına etkisini belirlemek için iç ortam hava sıcaklığı ile nem değerleri uygun algılayıcılarla ölçülmüştür Ağların bitki gelişimi üzerine etkisini belirlemek amacıyla ışık seçici ağlar ve açık tarla koşullarında domates bitkisi yetiştirilmiştir. Elde edilen bulgulara göre \% 40 gölgeleme oranl yeşil ağ toplam ışınım ve PAR bandında en yüksek geçirgenliği göstermiştir.
\end{abstract}

\section{ARTICLE INFO}

Received 31 August 2018

Received in revised form 21 November 2018 Accepted 21 November 2018

\section{Keywords:}

Shade nets

Total radiation

PAR

Temperature

Tomato

\begin{abstract}
This study was conducted at the research and application farm of Faculty of Agriculture, Akdeniz University in Antalya under open field $\left(756 \mathrm{~m}^{2}\right)$ conditions. The green shade nettings with shade factor of $40 \%, 55 \%, 75 \%$ and $95 \%$ were used as shading material in this study. Some radiometric properties (the global radiation and photosynthetically active radiation (PAR)) of shade nettings were determined in this study. Environment conditions inside the shade nets were also investigated. The air temperature and relative humidity were measured by appropriate sensors. In order to determine the effect of nets on plant growth, tomato plants were grown in shade nets and in open field conditions. According to the results, $40 \%$ shading green net showed the highest transmittance in total radiation and PAR band.
\end{abstract}

\section{Giriş}

Tarımsal üretimde bitkileri güneş 1şınlarının zararlı etkilerinden korumak için başvurulan yöntemlerin başında 1 şı seçici (foto-selektif) renkli gölgeleme ağlarının kullanılması gelmektedir (Ilic ve ark. 2011). Işık seçici ağların kullanımı aşırı 1şık zararını önlemesinin yanında, rüzgarın zararlı etkisini önlemekte, kuş ve viral hastalıkları taşıyan böcekleri bitkilerden uzak tutmakta ve bitkilerin bulunduğu ortamda sicaklığın yükselmesini de önlemektedir (Shahak 2008; Teitel ve ark. 2008; Kittas ve Rigakis 2009). Iş̧k seçici ağlar, tarla koşullarında yetiştirilen bitkilerin örtülmesinde uygulanabildiği gibi seralarda, sera dış yüzeyine veya sera içinde bitkilerin üzerine örtülerek de uygulanabilmektedir (Shahak ve ark. 2004; Castronuovo ve ark. 2015; Nemera ve ark. 2015).

Işı seçici ağlar aşama aşama tüm dünyada kullanılmakta ve anılan ağlar farklı bitkilere, alanlara ve iklim faktörlerine bağlı olarak da değerlendirilebilmektedir (Shahak 2008). Bu ağlar aynı zamanda güneş ışınlarının farklı oranlarda filtrasyonu ile üründe fiziksel korumayı amaçlayan yeni bir tarımsal teknoloji konseptini sunmaktadır (Shahak ve ark. 2004; Shahak 2008). Işık seçici renkli gölgeleme materyalleri bitki tarafindan alınan ışığın spektral kalitesini ve miktarını etkileyebilecek özellik taşımaktadır ve son y1llarda, bitki gelişimi ve büyümesini teşvik edecek şekilde tasarlanmaktadır (Justen ve ark. 2012). Iş̧k seçici ağlar ayrıca aşırı güneş 1şınımı ve yüksek sıcaklıklardan bitkileri korumak için oluşturulan ve "ağ evleri" olarak da adlandırılan özel yapılarda örtü malzemesi olarak da kullanılmaktadırlar (Briassoulis ve ark. 2007). Işı seçici ağlar; materyal tipi, ipliklerin tip ve boyutları, tekstürü (örülme şekli), açıklık boyutu, gözeneklilik/dayanıklılık ve ağırlığı gibi farklı yapısal özelliklerinin yanı sıra renk, 
geçirgenlik/yansıma/gölgeleme faktörü gibi radyometrik özellikler, hava geçirgenliği gibi fiziksel özellikler ile çekme dayanımı, mukavemet, kopmada uzama ve esneklik gibi mekanik özellikleri ile karakterize edilmektedir. Netlerin genişlik ve uzunlukta değişmektedir. Genişlikleri $1 \mathrm{~m}$ ile $6 \mathrm{~m}$ arasında değişirken netin tipine bağlı olarak $12 \mathrm{~m}$ ile $20 \mathrm{~m}$ 'ye kadar çıkabilmektedir. Uzunlukları ise $25 \mathrm{~m}$ ile $300 \mathrm{~m}$ arasında değişmektedir (Castellano ve ark. 2005; Castellano ve ark. 2008). Materyal tipi olarak tarımsal ağlarda ağırlıklı olarak yüksek yoğunluklu polietilen $\left(\gamma_{\mathrm{HDPE}}=940-960 \mathrm{~kg} \mathrm{~m}^{-3}\right)$ malzeme kullanılmakta olup dokumasız (örülmemiş) üretimde polipropilen $\left(\gamma_{\mathrm{PP}}=900-910 \mathrm{~kg} \mathrm{~m}^{-3}\right)$ malzeme de ham madde olarak kullanılmaktadır. Polipropilen malzemeden üretilen ağlar bahçe bitkileri ve meyve bahçelerinde bitkilerin üzerine direkt örtü olarak kültivasyonu yağmur, don ve rüzgardan korumak için uygulanır. $\mathrm{Bu}$ tip ağlar çok düşük yapısal dayanım ile karakterize edilmekte ve herhangi bir yapı iskeletinde örtü malzemesi olarak kullanılmamalıdır. Yüksek yoğunluklu polietilen malzeme ile üretilen ağların iki ana tipi vardır. Bunlar yuvarlak monofil (tek lifli) veya düz şerit tiptir. Işık seçici ağların örgü açıklıkları kullanım amacına göre; insekt netler (0.2-3.1 mm), gölgeleme ağları: $(1.7-7.0 \mathrm{~mm})$, anti-dolu netler $(2.5-4.0 \mathrm{~mm})$, rüzgar kırıcı netler $(1.8-7.0 \mathrm{~mm})$, anti-kuş netleri $(3.0-4.0 \mathrm{~cm})$ olmak üzere 5 tipte gruplandırılırlar (Castellano ve ark. 2008).

En yaygın ağ renkleri siyah, yeşil ve şeffaf renktir. Şeffaf renkli ağlarda netin gölgeleme etkisi net performansının (gölgeleme ağı olarak) negatif bir sonucu olarak nitelendirilmektedir. Siyah renkli ağlar genellikle gelen solar radyasyonu azaltmada süs bitkileri ve fidanlıklarda gölgeleme (\% 40-\% 80 gölgeleme oran1) amaçlı kullanılmakla birlikte elma bahçelerinde insect koruma amaçlı da kullanılmaktadır (Castellano ve ark. 2008). Renkli ağlar (kırmızı, sarı, mavi, yeşil vb.) siyah renkli 1 şı seçici ağların tersine güneşin $U V$, görülebilir veya uzak kırmızı 1şınım dalga bandından gelen 1şınımı farklı ve spesifik bir şekilde modifiye edecek şekilde geliștirilmiștir. Sedef, beyaz ve gri renkli ağlar nötr (renksiz) renkli ağlar olarak adlandırılmakta UV ve yakın kızıl ötesindeki spektral band1 absorbe ederler (Shahak ve ark. 2004; Shahak 2008; Castellano ve ark. 2008). Şeffaf renkli ağlar ise çevresel zararlar (dolu zararı vb.) veya böcek zararı için kullanılırlar. Bu ağlar geçirdikleri 1şınımı saçarak ortama aktarırlar ancak ışığın bileşimini niteliğini değiştirmezler (Shahak 2008). Siyah ve yeşil renkli 1şık seçici ağlar genellikle Akdeniz ülkelerinde sıcak periyotlarda açık tarla koşullarında veya sera örtü malzemesinin üstünde veya altında sera içindeki yüksek sıcaklıkları azaltmak için kullanılırlar (Shahak ve ark. 2004). Işık seçici ağların \% 10'dan \% 90'a kadar değiş̧ebilen gölgeleme faktörü ise gelen güneş 1şınımını azaltmada ağın kapasitesini temsil etmektedir (Schettini 2011). Birçok tarımsal uygulamada, netin radyometrik özellikleri yetiştiriciler tarafından dikkate alınması gereken en önemli parametrelerdir. Materyallerin toplam 1şınım geçirgenliği (300-2500 nm) net house (ağ evleri) içerisine ulaşan enerjinin miktarını ölçmede önemlidir. Nitekim anılan enerji ağ evlerinin mikrokliması üzerinde önemli bir etkiye sahiptir. Fotosentetik Aktif Radyasyon (PAR, 400-700 nm) geçirgenliği ise agronomik açıdan en önemli parametre olup bitkilerin fotosentez ve büyümesi için gereklidir (Castellano ve ark. 2008).

Bu çalışmada, son yıllarda tarımsal üretimde ürün kalitesini iyileştirmeye yönelik çevre dostu bir uygulama olan yeşil renkli 1şık seçici ağların Antalya ekolojik koşullarında toplam ışınım, PAR gibi bazı fiziksel özellikleri ile bu özelliklerine bağlı olarak ortam mikroklima (sıcaklık ve nem) koşulları ve verim üzerine etkisi araştırılmıştır.

\section{Materyal ve Yöntem}

Araştırma, Akdeniz Üniversitesi Ziraat Fakültesi Araştırma ve Uygulama Arazisi'nde yaklaşık $756 \mathrm{~m}^{2}$ lik açık tarla koşullarında 2015-2016 yılı Nisan ve Ağustos ayları arasında yürütülmüştür.

\subsection{Bitkisel materyal}

Araştırmada, ülkemiz ve Antalya için en büyük üretim alanı ve üretim miktarına sahip olan domates bitkisi kullanılmıştır. Domates çeşidi olarak Türkiye'de açık tarla yetiştiriciliğinde yaygın kullanılan sanayi tipi Ankon ve Beef çeşitleri tercih edilmiştir. Çeşitler toplam deneme alanı $(14 \times 56 \mathrm{~m})$ boyutları yarı yarıya olacak şekilde dikilmiştir. Çalışmada bitki materyali olarak kullanılacak fideler Antalya'da ticari olarak hazır fide yetiştiriciliği yapan bir firmadan fide olarak temin edilmiş olup dikim aşamasına gelmiş fideler (4-5 gerçek yaprakl1) 25 Nisan 2016 tarihinde araziye tek sıraya dikim $(50 \times 70 \mathrm{~cm})$ şeklinde şaşırtılmıştır.

\subsection{Uygulama alanında kullanılacak gölgeleme ağları}

Çalışmada deneme materyalleri olarak ülkemizde ve diğer Akdeniz ülkelerinde de yaygın olarak kullanılan yeşil renkli gölgeleme ağları kullanılmıştır. Yeşil renkli gölgeleme ağları piyasada 4 farklı gölgeleme oranında ( $\% 40, \% 55, \% 75$ ve $\%$ 95) mevcut bulunmaktadır. Anılan çalışmada tüm gölgeleme oranları denemeye tabi tutulmuştur. Buna bağlı olarak Antalya ekolojik koşullarında domates bitkisi için yeşil renkte en uygun gölgeleme oranı belirlenebilmiştir. Denemede kullanılan 1 şık seçici ağların gölgeleme oranı ile ağların en ve boy değerleri verilmiştir. Ağların en ve boy değerleri; \% 40 ve $\% 55$ yeşil gölgeleme oranlı ağda en $8 \mathrm{~m}$ boy $200 \mathrm{~m}$; \% 75 ve \% 95 yeşil gölgeleme oranlı ağda en $6 \mathrm{~m}$ boy $100 \mathrm{~m}$ 'dir. Dört farklı gölgeleme oranlı yeşil ağ $504 \mathrm{~m}^{2}$ lik bir alanda 3 tekerrürlü olarak denemeye alınmıştır. Her bir ağın kapladığı alan $126 \mathrm{~m}^{2}$ olup (her bir tekerrür $42 \mathrm{~m}^{2}$ ) toplam alanın $252 \mathrm{~m}^{2}$ lik kısmı kontrol grubu (açık alan) olarak değerlendirilmiştir (Şekil 1). Gölgeleme ağları $14 \mathrm{~m} \times 36 \mathrm{~m}$ boyutlarında yerden yüksekliği $2.7 \mathrm{~m}$ olan düz çatılı sağlam profil demir malzemeden inşa edilmiş bir konstrüksiyon üzerine serilmiştir.

\subsection{Gölgeleme ağlarının bazı radyometrik özellikleri}

Çalışmada gölgeleme malzemelerinin toplam ışınım ve PAR gibi bazı fiziksel özellikleri belirlenmiştir. Bu amaç için 1Şık seçici ağların toplam 1şınım geçirgenliğini belirlemede 300$2800 \mathrm{~nm}$ dalga boyuna duyarlı 5 adet piranometre kullanılmıştır. Piranometrelerin 4 tanesi uygulama alanının içerisinde 1şı seçici ağların altına bir diğeri ise kontrol grubu olarak nitelendirilen herhangi bir gölgeleme materyali olmayan alana yerleştirilmiştir. Anılan piranometre'nin hassasiyeti 5-20 $\mu \mathrm{V} \mathrm{W}^{-1} \mathrm{~m}^{-2}$ arasında değişmektedir.

Araştırmada 1şık seçici ağların fotosentetik etkin 1şınım (PAR) geçirgenliğini belirlemede 400-700 nm dalga boyuna duyarlı 5 adet quantum algılayıcısı kullanılmıştır. Quantum algılayıcılarının 4 tanesi farklı renklerde belirlenen 1şık seçici ağların her birinin altına yerleştirilirken bir diğeri kontrol grubu olarak belirlenen ve herhangi bir sşık seçici ağın bulunmadığ alan üzerine yerleştirilmiştir. Anılan algılayıcıların hassasiyeti 4-10 $\mu \mathrm{V} \mu \mathrm{mol}^{-1} \mathrm{~m}^{-2} \mathrm{~s}^{-1}$ arasında değişmektedir. 


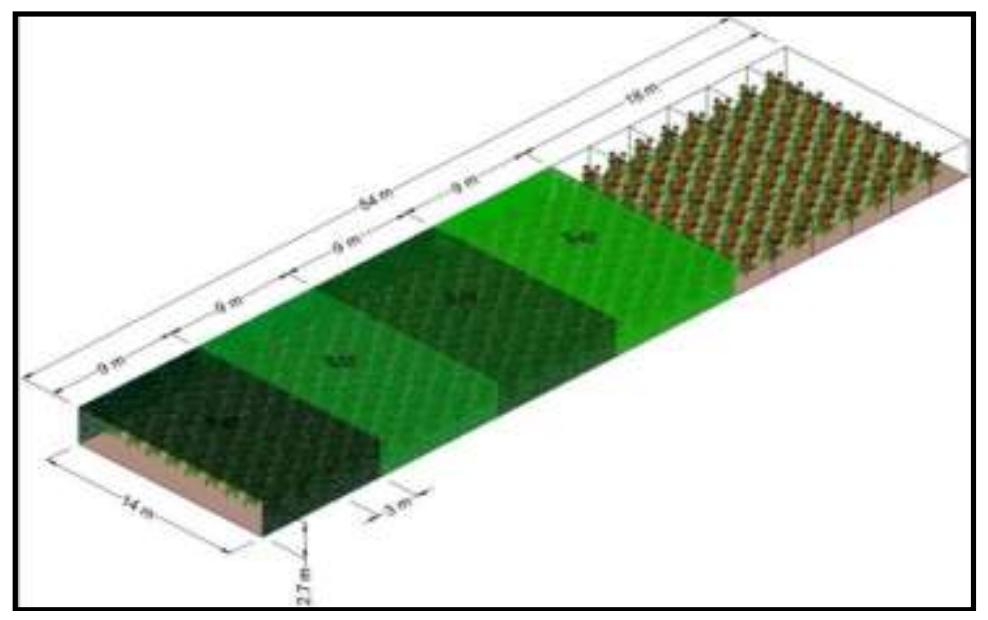

Şekil 1. Deneme planı.

Figure 1. The experimental design.

Piranometreler ve quantum algılayıcılar uygulama alanının yapı elemanlarının gölgeleme etkisinden etkilenmeyecek orta kısma gelecek şekilde toprak seviyesi ile yataylığı sağlanan $2.0 \mathrm{~m}$ yüksekliğindeki sehpalar üzerine yerleştirilmiştir (Kittas ve ark. 2006). Araştırmada gölgeleme ağlarının toplam ışınım ve PAR geçirgenlikleri Eşitlik 1 ve Eşitlik 2 kullanılarak belirlenmiştir (Kittas ve ark. 1999).

$$
\tau_{T}=\frac{T_{i}}{T_{o}} \times 100
$$

Eşitlikte;

$\tau_{\mathrm{T}}$ : Ağların toplam ışınım geçirgenliği (\%),

Ti: A ğ kullanılan alana ulaşan 1 şınım $\left(\mathrm{W} \mathrm{m}^{-2}\right)$,

To: Ağ kullanılmayan alana ulaşan 1 şınım $\left(\mathrm{W} \mathrm{m}^{-2}\right)$.

$$
\tau_{P}=\frac{P_{i}}{P_{o}} \times 100
$$

\section{Eşitlikte;}

$\tau_{\mathrm{P}}:$ Ağların PAR geçirgenliği (\%),

Pi: A $\breve{g}$ kullanılan alana ulaşan PAR $\left(\mathrm{mmol} \mathrm{m}^{-2} \mathrm{~s}^{-1}\right)$,

Po: Ağ kullanılmayan alana ulaşan PAR $\left(\mathrm{mmol} \mathrm{m}^{-2} \mathrm{~s}^{-1}\right)$.

Deneme süresince 1şık seçici ağların toplam 1şınım ve PAR geçirgenliklerinin belirlenmesinde açık gökyüzü koşulları ve saat 06:00-18:00 zaman aralığı dikkate alınmıştır. (Geoola ve ark. 1998; Geoola ve ark. 2004; Kittas ve ark. 2006). Tüm veriler incelendiğinde her ay için belirtilen koşulları sağlayan (algılayıcılardan sağlıklı verilerin alındığı) 3 açık gün belirlenerek geçirgenlik değerlerinin ortalaması anılan ay için geçirgenlik değeri olarak kabul edilmiştir (Cemek ve Demir 2005).

Çalışmada gölgeleme ağlarının zamana bağlı olarak toplam ışınım ve PAR geçirgenliklerindeki kayıplar Eşitlik 3 yardımı ile belirlenmiştir (Geoola ve ark. 1994; Geoola ve ark. 2004).

$$
\text { Geçirgenlik Kaybı }=\left(\frac{\mathrm{T}_{\text {yeni }}-\mathrm{T}}{\mathrm{T}_{\mathrm{yeni}}}\right) \times 100
$$

Eşitlikte;

Tyeni: Yeni örtü malzemesinin ışınım geçirgenliği (\%),

$\mathrm{T}$ : Belli bir zaman periyodundan sonraki örtünün 1şınım geçirgenliği (\%).

\subsection{Gölgeleme ăglarında ortam mikrokliması}

Çalışmada anılan malzemelerinin ortam mikrokliması (hava sıcaklığı ve nem) üzerine etkisi araştırılmıştır. Araştırma kapsamında sıcaklık ve bağıl nem ölçümünde, programlanabilir ve kayıt özelliği olan, $-10^{\circ} \mathrm{C}$ ile $+50{ }^{\circ} \mathrm{C}$ arası sıcaklıkta ve $\% 0$ $\% 100$ arası bağıl nemde ölçüm yapabilen 5 adet cihaz kullanılmıştır. Sıcaklık ve nem veri kayıt cihazının 4 adeti, farklı gölgeleme oranlarına sahip yeşil renkli 1şık seçici ağların her birinin altına, bir diğeri ise kontrol gurubu olarak belirlenen ve herhangi bir gölgeleme ağının bulunmadığı alana yerleştirilmiştir. Anılan cihazlar uygulama alanındaki yapı elemanlarının gölgeleme etkisinden etkilenmeyecek şekilde deneme parsellerinin orta kısmına toprak seviyesi ile yataylığ sağlanan $1.5 \mathrm{~m}$ yüksekliğindeki sehpaların ayağına yerleştirilmiştir (Barroso ve ark. 1999). Işık seçici ağların aylık ortalama, minimum ve maksimum sıcaklık ve nem değerleri ile ağların toplam 1şınım ve PAR geçirgenlik değerleri açık gökyüzü koşulları için gün boyunca 24 saatlik zaman aralığına göre kaydedilmiş ve değerlendirilmiştir.

\subsection{Veri kayıtlarında kullanılan aletler}

Araştırmada piranometre, quantum (PAR) algılayıcılarından gelen sayısal verilerin toplanması ve bilgisayara aktarılması için 15/60 analog kanal ve 128000 okuma hafizas1 olan bir veri kayıt cihazı kullanılmıştır. Anılan algılayıcıların veri kayıt cihazı üzerindeki uygun kanal girişleri ile bağlantısı sağlandıktan sonra cihaz deneme alanında dış atmosfer koşullarına karşı koruma sağlaması için meteorolojik alet siperinin içine yerleştirilmiştir. Veri kayıt cihazı gölgeleme ağları ile kapatılmış ortamdaki toplam 1şınım, PAR algılayıcılarından her 10 dakikada bir veri alımı sağlayacak şekilde programlanmıştır. Kaydedilen tüm veriler değerlendirilmek üzere veri kayı cihazından bilgisayar ortamına aktarılmıştır. PC ortamında ise her 10 dakikada bir kaydedilen verilerin saatlik ortalaması, günlük ortalaması ve aylık ortalaması saptanmıştır. Sıcaklık ve nem algılayıcıları da benzer şekilde programlanmıştır.

Çalışmada dış ortam toplam ışınım, PAR değerini ölçen aletler meteorolojik alet siperi üzerine (piranometre ve quantum algılayıcısı) ve sıcaklık ve nem değerlerini ölçen aletler ise alet siperi içine yerleştirilmiştir. Denemede veri alımı 16 Haziran 2016 tarihi itibariyle başlamış ve 18 Ağustos 2016 tarihine kadar devam etmiştir. 


\subsection{Kültürel işlemler, sulama ve gübreleme}

Araştırma alanında deneme süresince yetiștirme ortamında gerekli bakım, gübreleme, bitki koruma ve diğer kültürel işlemler uygun bir şekilde yürütülmüştür. Domates bitkisi, sulama suyu yönetiminin en etkin bir şekilde yapılabildiği ve diğer sulama yöntemlerine oranla su kullanımının daha kontrollü bir şekilde uygulanabildiği damla sulama yöntemi ile sabit aralıklarla deneme başından son hasada kadar 2 günde bir sulanmıștır. Araștırmada, bitkilerin tarlaya dikiminden hasada kadar olan vejetasyon süresince $1 \mathrm{~atm}$ işletme basıncinda $21 \mathrm{~h}^{-1}$ damlatıcı özelliğine sahip damla sulama sistemi kullanılmıştır. Sulamalarda, parsellere uygulanacak su miktarları diş ortama konan A-Sınıfı Buharlaşma Kabından alınan ölçümler (buharlaşmanın tamamı) kullanılarak hesaplanmıştır. Anılan kap, $121 \mathrm{~cm}$ çapında, $25.4 \mathrm{~cm}$ yüksekliğinde olup $2 \mathrm{~mm}$ kalınlığındaki galvanizli saçtan yapılmış, gümüş gri renge boyalı, üstü açık bir silindirden oluşmaktadır (Doorenbos ve Pruitt 1977). Araştırmada A- Sınıfı Buharlaşma Kabından oluşan buharlaşmanın \% 100'ü tüm gruplara uygulanmıştır. Böylece parsellere eşit oranda sulama suyu sağlanmıştır. ASınıfı Buharlaşma Kabından mm olarak ölçülen iki günlük buharlaşma değerlerinin \% 100'ü alınarak parseller için gerekli sulama suyu miktarı mm olarak hesaplanmış ve buharlaşma değerlerine dayalı olarak belirlenen sulama suyu miktarı Eşitlik 4 yardımıyla litreye dönüştürülerek eşit bir biçimde uygulanmıştır. (Kırda ve ark. 2004). Böylece tüm deneme gruplarına eşit sulama suyu uygulandığ 1 için evapotranspirasyona bağlı olarak sulamaların ortam nemi ve verim üzerine etkisinin farklı gölgeleme gruplarında aynı düzeyde olması sağlanmıştır.

$$
I=k p \times k c \times E p \times A
$$

(Eşitlik 4)

Eşitlikte;

I: Sulama suyu (litre bitki ${ }^{-1}$ ),

kp: A- Sınıfi Buharlaşma Kabı katsayısı olup denemede 1.0 olarak alınd1,

kc: Bitki katsayısı olup bitki gelişim dönemine bağlı olarak 0.45 ile 1.25 arasinda alındı (fide periyotu 0.45 , vejetatif periyot 0.75 , çiçeklenme 1.15 , meyve tutumu 0.85 , olgunlaşma 0.6 ) (Doorenbos ve Kassam 1979),

Ep: Sulama aralığına karşılık gelen A-Sınıfı Buharlaşma Kabından alınan toplam buharlaşma ( $\mathrm{mm}$ ),

A: Bir parselin alanıdır $\left(\mathrm{m}^{2}\right)$.

Çalışmada gölgeleme ağlarının bitki gelişimi üzerine etkisini belirlemek amacıyla Ankon çeşidi domates bitkisi üzerinde çeşitli gözlem ve ölçümler 15 gün aralıklarla yapılmıştır. Seçilen gözlem bitkilerinde bitki boyu $(\mathrm{cm})$, kök boğazı kalınlığı (mm), yaprak sayısı (adet bitki ${ }^{-1}$ ) gibi vejetatif gelişim ve verim (ton ha ${ }^{-1}$ ) parametreleri ile ortalama meyve ağırlığ $1\left(\right.$ gr adet $\left.^{-1}\right)$, meyve çapı $(\mathrm{mm})$, meyve suyunda EC ve $\mathrm{pH}$ ile suda çözünebilir kuru madde (SÇKM, Briks, \%) gibi meyve kalite parametreleri belirlenmiştir. Elde edilen verileri değerlendirmek için SPSS 17.0 programından yararlanılmıştır.

\section{Bulgular ve Tartışma}

\subsection{Gölgeleme ağlarının toplam ışınım ve PAR geçirgenliği}

Çalışmada, tüm fideler tuttuktan ve çiçeklenmenin gerçekleşmeye başladığı fide dikiminden 52 gün sonra (16.06.2016) gölgeleme ağları deneme alanına serilmiştir (Kittas ve Rigakis 2009). Gölgeleme ağlarının toplam 1şınım, PAR gibi bazı radyometrik özellikleri ise anılan tarihten sonra değerlendirilmeye başlamıştır. Denemede kullanılan farklı gölgeleme oranlarına sahip yeşil renkli gölgeleme ağının toplam 1şınım geçirgenliğinin (300-2800 nm) $\left(\mathrm{W} \mathrm{m}^{-2}\right)$ zamana bağlı aylık (Haziran 2016-Ağustos 2016) değişim ortalamaları Çizelge 1'de sunulmuştur. Gölgeleme ağlarının toplam ışınım geçirgenliği (\%) ile zamana bağlı toplam 1şınım geçirgenliğindeki kayıplar (\%) Şekil 2'de gösterilmiştir. Çizelge 1 'de görüldüğ̈ gibi en fazla toplam ışınım değerleri açık tarla koşullarında elde edilmiştir bunu sırası ile \% 40, \% 55, \% 75 ve $\%$ 95'lik ağ grupları izlemiştir. Şekil 2'de görüldüğü gibi deneme süresince $\% 40$ yeşil gölgeleme ağı en yüksek toplam 1şınım geçirgenliğini \%95 yeşil gölgeleme ağı ise dokuma sıklığına bağlı olarak en düşük geçirgenliği göstermiştir. \% 55 ve $\% 75$ gölgeleme açıklıklı yeşil ağların ışınım geçirgenliği ise bu grupların ortasında yer almıştır. Deneme süresince bitkisel üretimde görülen gözlemlerde de \% 95'lik yeşil ağda gölgeleme yoğunluğunun fazla olması nedeniyle meyve gelişimi olmamıştır. Meyveler genel olarak en fazla ceviz büyüklügünde kalmış, herhangi bir kızarma gerçekleşmemiştir. Dolayısı ile anılan açıklık oranının bitkisel üretim için kullanılamayacağı ortaya çıkmıştır. Buna karşılık meyve gelişimi ve verim bakımından \% 40'llk yeşil gölgeleme ağ 1 en iyi sonucu vermiştir $(P<0.05)$ (Çizelge 3). Şekil 2'de görüldüğü gibi \% 40, \% 55, $\% 75$ ve \%95 açıklıklı yeşil gölgeleme ağlarının başlangıç toplam 1şınım geçirgenlik değerleri (Haziran ayı) 3 aylık kullanım periyodunun sonunda sirası ile $\% 3.6, \% 4.6$, \% 6.9 ve $\% 71.4$ oranında azaldığı belirlenmiştir (Eşitlik 3).

Çizelge 1. Güneşli günler için gölgeleme ağlarının ayllık ortalama toplam 1şınım geçirgenliği.

Table 1. Monthly average total radiation transmittance of shade nettings for sunny days.

\begin{tabular}{|c|c|c|c|c|c|}
\hline \multirow[t]{2}{*}{ Aylar } & \multicolumn{4}{|c|}{$\begin{array}{l}\text { Gölgeleme ağları altına ulaşan iç } \\
\text { ortam ışınım değerleri }\left(\mathrm{W} \mathrm{m}^{-2}\right)\end{array}$} & \multirow{2}{*}{$\begin{array}{c}\text { Diş ortam } \\
\text { (Kontrol) 1şınım } \\
\text { değerleri }\left(\mathrm{W} \mathrm{m}^{-2}\right)\end{array}$} \\
\hline & $\% 40$ & $\% 55$ & $\% 75$ & $\% 95$ & \\
\hline Haziran & $323.8 *$ & 251.8 & 171.4 & 43.4 & 582.4 \\
\hline Temmuz & 336.1 & 260.0 & 174.5 & 53.7 & 590.8 \\
\hline Ağustos & 293.4 & 220.0 & 147.3 & 11.2 & 541.7 \\
\hline
\end{tabular}

*Tablodaki değerler seçilen 3 açık gün ortalamasıdır.

Castellano ve ark. (2008), gölgeleme netlerinin sera içindeki veya ağ evleri içerisindeki hava sıcaklığını azaltmak ya da bazı süs bitkileri gibi gölge seven bitkilerde 1 şınım seviyesini azaltmak için solar radyasyonu azalttığını ve gölge sistemlerinin etkinliğinin netin gölgeleme faktörüne bağlı olduğunu bildirmişlerdir. Nitekim bu çalışmada da gölgeleme oranı arttıkça netin ışınım geçirgenliği azalmıştır. Briassoulis ve ark. (2007), 1şık seçici ağların 1şınım geçirgenliğinin \% 20-70 aralığında değiştiğini bildirmişlerdir. Nangare ve ark. (2015), yaptıkları çalışmada \% 35 ve \% 75'lik yeşil gölgeleme açıklıklı net house altındaki solar radyasyon değerlerinin açık tarla koşulları ile kıyaslandığında sırası ile \% 43-45 ve \% 16-17.5 arasında azalma kaydedildiğini bildirmişlerdir. Elde edilen bulguların literatür ile uyumlu olduğu söylenebilir. Gölgeleme ağlarının toplam ışınım geçirgenliğinin tipik bir yaz gününde günün saatine bağlı değişimleri güneşli ve bulutlu gökyüzü koşulları için Şekil 3'de sunulmuştur.

Denemede kullanılan gölgeleme ağlarının PAR geçirgenliğinin (400-700 nm) $\left(\mathrm{mmol} \mathrm{m}^{-2} \mathrm{~s}^{-1}\right)$ zamana bağlı aylık (Haziran 2016-Ağustos 2016) değişim ortalamaları Çizelge 2'de sunulmuştur. Gölgeleme ağlarının PAR geçirgenliği (\%) ile zamana bağlı PAR geçirgenliğindeki kayıplar (\%) ise Şekil 4'de gösterilmiştir. Şekil 4'de görüldüğü gibi tüm gölgeleme ağları gelen PAR ışınımını açık alan ile karşılaştırıldığında (Çizelge 2) 
azaltmıştır. PAR geçirgenliğindeki değişim toplam ışınım geçirgenliğindeki değişimle paralellik göstermektedir. En az PAR 1şınımını \% 95'lik gölgeleme ağı, en fazla PAR 1şınımını ise $\% 40$ 'lık gölgeleme ağı göstermiştir. \% 55 ve \% 75'lik ağlar birbirine yakın geçirgenlik değerleri ile yukarda belirilen iki grubun ortasında yer almıştır. Kittas ve Rigakis (2009), yaptıkları çalışmada \% 34 gölgeleme yoğunluklu yeşil ağın PAR geçirgenliğini \% 70 olarak saptamışlardır. Elde edilen bulgulara göre gerek PAR geçirgenliği gerekse bitkisel üretim (Çizelge 3) açısından en uygun ağın \% 40 gölgeleme oranlı yeşil ağ olduğu söylenebilir. Gölgeleme ağlarının PAR ışınım geçirgenliğinin tipik bir yaz gününde, günün saatine bağlı değişimleri güneşli ve bulutlu gökyüzü koşulları için Şekil 5'de sunulmuştur.

Çizelge 2. Güneşli günler için gölgeleme ağlarının ayllık ortalama PAR geçirgenliği.

Table 2. Monthly average PAR transmittance of shade nettings for sunny days.

\begin{tabular}{cccccc}
\hline \multirow{2}{*}{ Aylar } & \multicolumn{2}{c}{$\begin{array}{c}\text { Gölgeleme ağları altına ulaşan iç ortam } \\
\text { PAR değerleri }\left(\mathrm{mmol} \mathrm{m}^{-2} \mathrm{~s}^{-1}\right)\end{array}$} & $\begin{array}{c}\text { Diş ortam } \\
\text { (Kontrol) PAR } \\
\text { değerleri }\end{array}$ \\
\cline { 2 - 4 } & $\% 40$ & $\% 55$ & $\% 75$ & $\% 95$ & $\begin{array}{c}\text { \% } 50.5 \\
\left(\mathrm{mmol} \mathrm{m}^{-2} \mathrm{~s}^{-1}\right)\end{array}$ \\
\hline Haziran & $482.9 *$ & 210.3 & 200.5 & 20.2 & 561.5 \\
Temmuz & 483.0 & 206.7 & 188.6 & 5.5 & 565.5 \\
A ğustos & 425.7 & 186.6 & 169.9 & 6.6 & 537.5 \\
\hline
\end{tabular}

Çizelge 3. Farklı gölgeleme oranlı ağlarda bitki gelişim, verim ve meyve kalite parametreleri.

Table 3. Plant growth, yield and fruit quality parameters in different shading ratio nets.

\begin{tabular}{|c|c|c|c|c|c|}
\hline \multirow[b]{2}{*}{ Parametre } & \multicolumn{5}{|c|}{ Gölgeleme Uygulamaları } \\
\hline & $\begin{array}{l}\text { \% } 40 \\
\text { Yeşil } \\
\text { Ağ }\end{array}$ & $\begin{array}{c}\text { \% } 55 \\
\text { Yeşil } \\
\text { Ağ }\end{array}$ & $\begin{array}{c}\% 75 \\
\text { Yeşil } \\
\text { Ağ }\end{array}$ & $\begin{array}{c}\% 95 \\
\text { Yeşil } \\
\text { A ğ }\end{array}$ & $\begin{array}{l}\text { Diş ortam } \\
\text { (Kontrol) }\end{array}$ \\
\hline $\begin{array}{l}\text { Bitki Boyu } \\
\quad(\mathrm{cm})\end{array}$ & 63.8 & 57.0 & 58.8 & 47.3 & 58.0 \\
\hline $\begin{array}{c}\text { Kök boğaz } \\
\text { kalınlığ } \\
(\mathrm{mm}) *\end{array}$ & $19.3 \mathrm{a}^{f}$ & $17.2 \mathrm{ab}$ & $18.4 \mathrm{ab}$ & $14.7 b$ & $21.4 \mathrm{a}$ \\
\hline $\begin{array}{c}\text { Yaprak sayıs1 } \\
\left(\text { yaprak bitki }^{-1}\right)\end{array}$ & 60 & 62 & 61 & 49 & 70 \\
\hline Verim $\left(\mathrm{t} \mathrm{ha}^{-1}\right) *$ & $141.4 \mathrm{a}^{f}$ & $73.8 \mathrm{c}$ & $71.4 \mathrm{~d}$ & $43.8 \mathrm{e}$ & $91.4 b$ \\
\hline $\begin{array}{c}\text { Ort. Meyve } \\
\text { ağırlığı (gr) * }\end{array}$ & $88.4 \mathrm{a}^{f}$ & $79.9 b$ & $70.8 \mathrm{c}$ & $70.2 \mathrm{c}$ & $60.4 \mathrm{~d}$ \\
\hline $\begin{array}{l}\text { Meyve Çap1 } \\
(\mathrm{mm}) *\end{array}$ & $49.9 \mathrm{a}^{f}$ & $47.1 \mathrm{~b}$ & $46.4 \mathrm{c}$ & $44.6 \mathrm{e}$ & $45.7 \mathrm{~d}$ \\
\hline $\operatorname{SÇKM~}(\%) *$ & $3.9 \mathrm{c}^{f}$ & $4.0 \mathrm{bc}$ & $4.2 b$ & $3.3 \mathrm{~d}$ & $5.2 \mathrm{a}$ \\
\hline $\mathrm{EC}\left(\mathrm{dS} \mathrm{m} \mathrm{m}^{-1}\right) *$ & $5.2 \mathrm{~d}^{f}$ & $4.8 \mathrm{e}$ & $6.0 \mathrm{a}$ & $5.3 \mathrm{c}$ & $5.5 b$ \\
\hline $\mathrm{pH} *$ & $4.4 \mathrm{~b}$ & $4.4 \mathrm{~b}$ & $4.3 \mathrm{c}$ & $4.3 \mathrm{c}$ & $4.6 \mathrm{a}$ \\
\hline
\end{tabular}

*: \%5 düzeyinde önemli, $f$ : Aynı satırda farklı harfle gösterilen değerler Duncan testine göre $\% 5$ önem seviyesinde farklıdır.

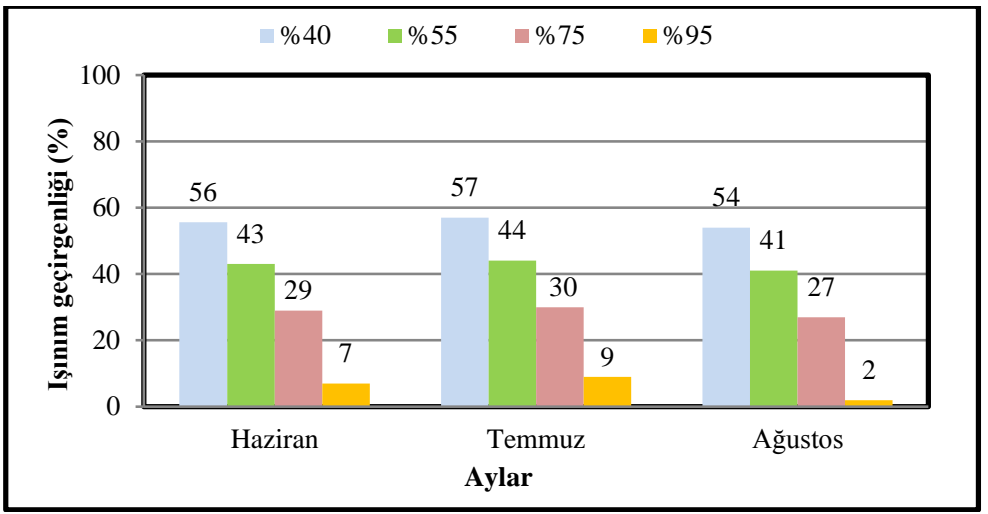

Şekil 2. Farklı gölgeleme oranına sahip yeşil renkli gölgeleme ağının toplam ışınım geçirgenliği (\%).

Figure 2. Temporal total radiation transmittance (\%) of green coloured shade net with different shading ratio.

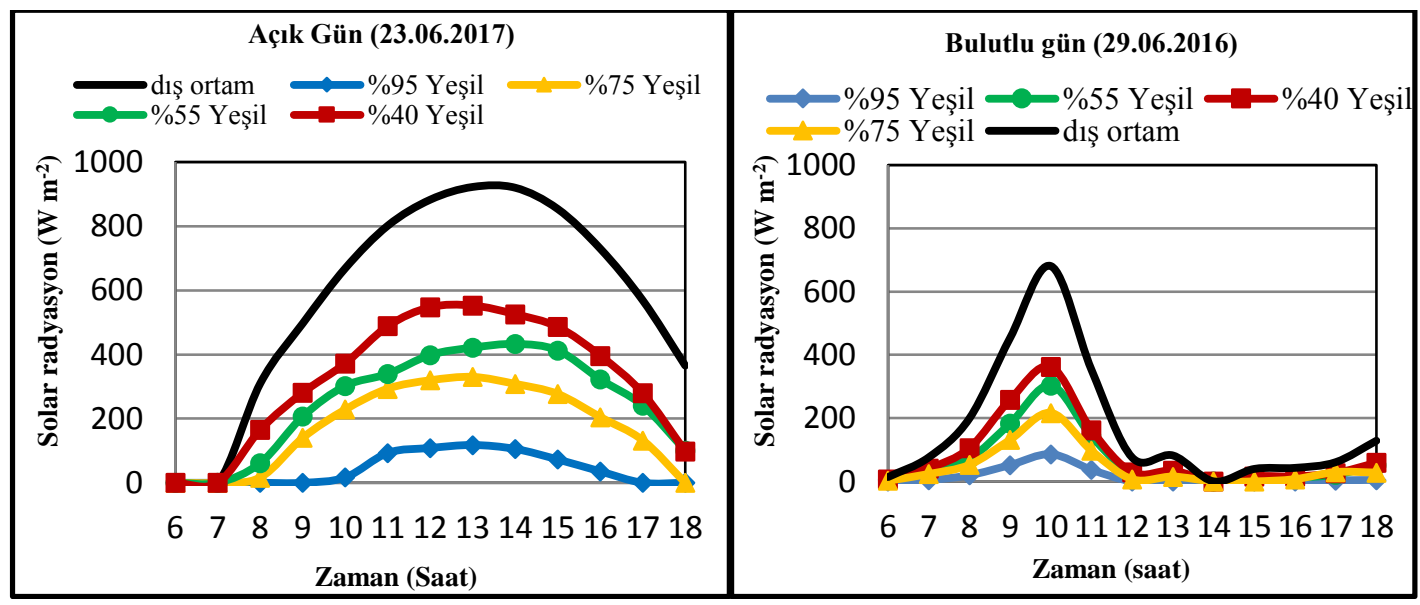

Şekil 3. Farklı gölgeleme oranlı ağların tipik yaz gününde günlük saatlik ortalama toplam ışınım geçirgenliği.

Figure 3. Total solar radiation of shade nets with different shading ratio; a typical summer day. 


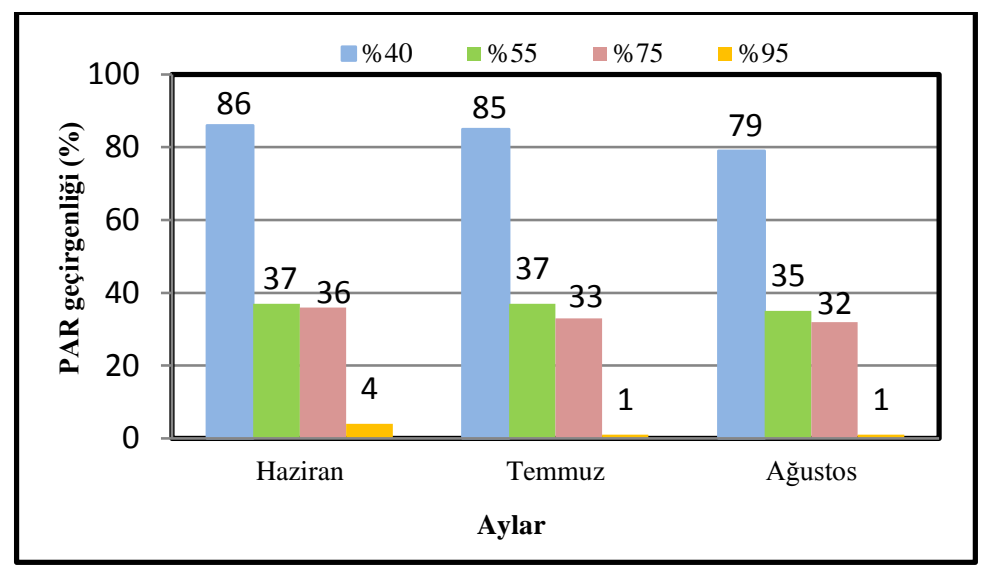

Şekil 4. Farklı gölgeleme oranına sahip yeşil renkli gölgeleme ağının zamana bağlı PAR geçirgenliği (\%).

Figure 4. Temporal PAR transmittance (\%) of green coloured shade net with different shading ratio.

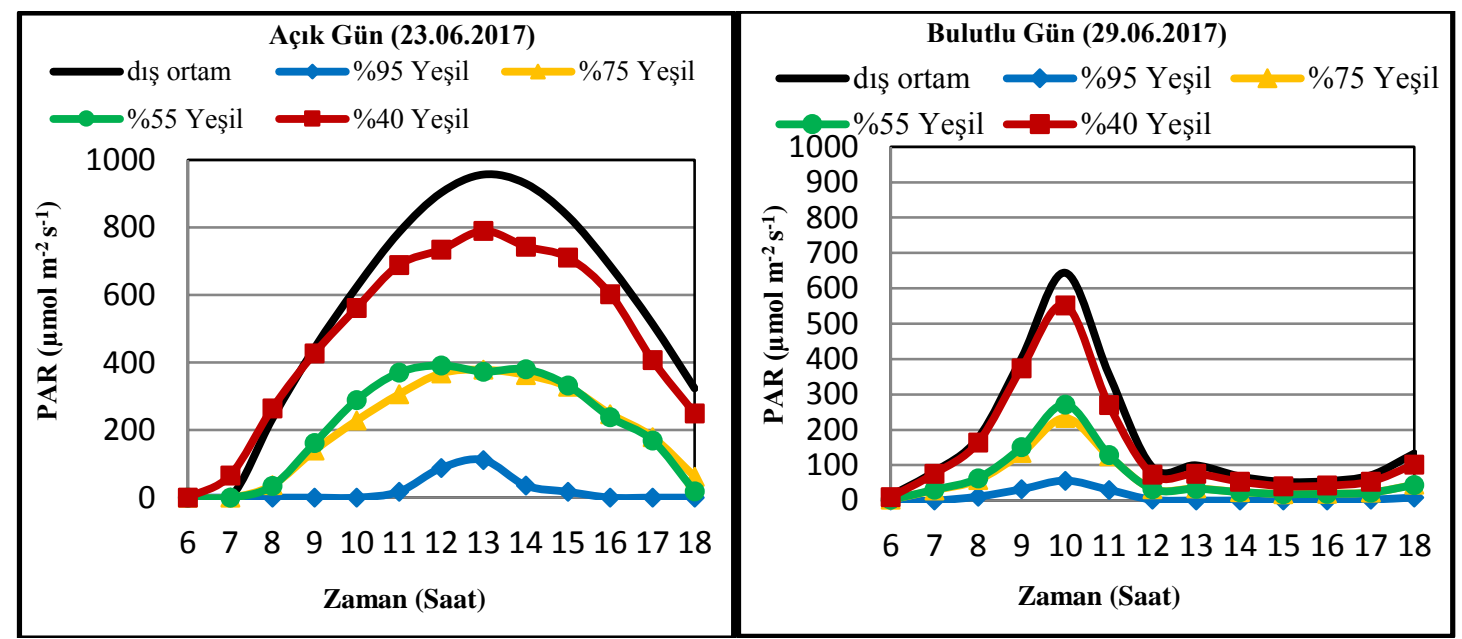

Şekil 5. Gölgeleme ağlarının tipik yaz gününde günlük saatlik ortalama PAR ışınım geçirgenliğinin zamana bağlı değişimi.

Figure 5. PAR radiation of shade nets with different shading ratio; a typical summer day.

\subsection{Gölgeleme ağlarında ortam mikrokliması}

Gölgeleme ağları altında elde edilen iç ve dış ortam sıcaklık ve nem ölçüm değerlerinin aylık değişimi Şekil 6 ve Şekil 7'de verilmiştir. Şekil 6 'da görüldügü gibi gölgeleme ağları altında ortalama günlük maksimum hava sıcaklığı değerleri açık alan ile karşılaştırıldığında daha yüksektir. Ancak ölçüm yapılan algılayıcılar gölge sıcaklığına dayalı ölçümler yaptığı için bu yükseklik düşürücü etki olarak değerlendirilmelidir. En yüksek hava sıcaklığı \% 40 gölgeleme ağı altında kaydedilmiştir (dış ortamdan 0.9 ile $3.6{ }^{\circ} \mathrm{C}$ daha yüksek). En düşük sıcaklıklar dış ortam koşullarında elde edilmiştir. Nitekim Arthurs ve ark. (2013), çalışmalarında fotoselektif ağlarla oluşturulmuş ağ evleri (kırmızı, mavi, siyah, sedef, açık alan) altında çevre koşullarını incelemişlerdir. Araştırmacılar ortalama günlük maksimum sıcaklık değerlerini dikkate almışlar ve anılan değerlerin ağ evleri altında diş ortam ve siyah nete göre yüksek olduğunu bildirmişlerdir. Kittas ve Rigakis (2009), ortalama hava sıcaklık değerlerinin net altında $\left(29.5^{\circ} \mathrm{C}\right)$ ve dış ortamda $\left(29.6^{\circ} \mathrm{C}\right)$ birbirine çok yakın olduğunu bu durumun konstrüksiyonun sadece üst kısmının örtülmesinden yanlarının açık kalmasından kaynaklandığını bildirmiştir. Abdrabbo ve ark. (2010), net kullanımının sıcaklık üzerinde kısıntılı bir etkisi olduğunu bildirmişlerdir.
Şekil 7'de görüldüğü gibi ağlar altındaki nem değerlerinin değişimi sıcaklık değerlerinde olduğu gibi birbirine benzerdir. Deneme süresince diş ortama göre daha düşük ( $\% 0.4$ ile \% 7.7) ortalama günlük minimum nem değerleri elde edilmiştir. Ilic ve ark. (2017), yaptıkları çalışmalarında netler altında mikroklimanın benzer olduğunu sıcaklık ve nem değerlerinin ise dış ortamdan biraz düşük olduğunu bildirmişlerdir.

\subsection{Gölgeleme ağlarında bitki gelişimi}

2015-2016 yılı bahar dönemi domates fideleri açık tarla koşullarında yetiştirme ortamına 25 Nisan 2016 tarihinde şaşırtılmış olup son hasat tarihi 09 Ağustos 2016'dır. 2016 bahar yetiştiricilik döneminde dikimden sonraki 68. ve 107. günler arasında 5 hasat yapılmıştır. Gölgeleme ağlarının deneme alanına serilmesi 16 Haziran 2016 olup anılan ağların bitki gelişimi üzerine etkisinin belirlenmesinde elde edilen bazı bitki büyüme (bitki boy, kök boğaz kalınlığı, yaprak sayısı), verim ve bazı meyve kalite parametreleri (ortalama meyve ağırlı̆̆ı, meyve çapı, suda çözünebilir kuru madde (SÇKM ), meyve suyunda EC ve pH) sanayilik Ankon çeşidi için Çizelge 3'de sunulmuştur. 


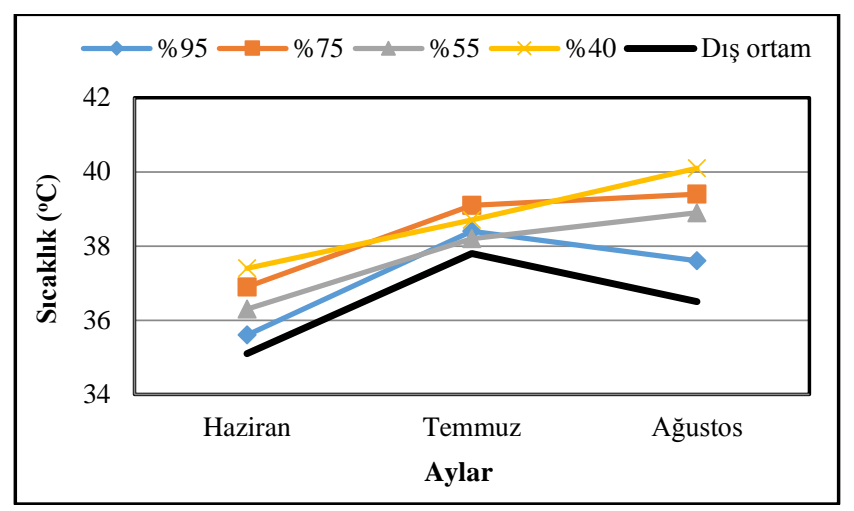

Şekil 6. Farklı gölgeleme oranlı ağların iç ve dış ortam aylık ortalama maksimum sıcaklık değerleri.

Figure 6. Monthly inside and outside average maximum temperaturse values for different shading ratio nets.

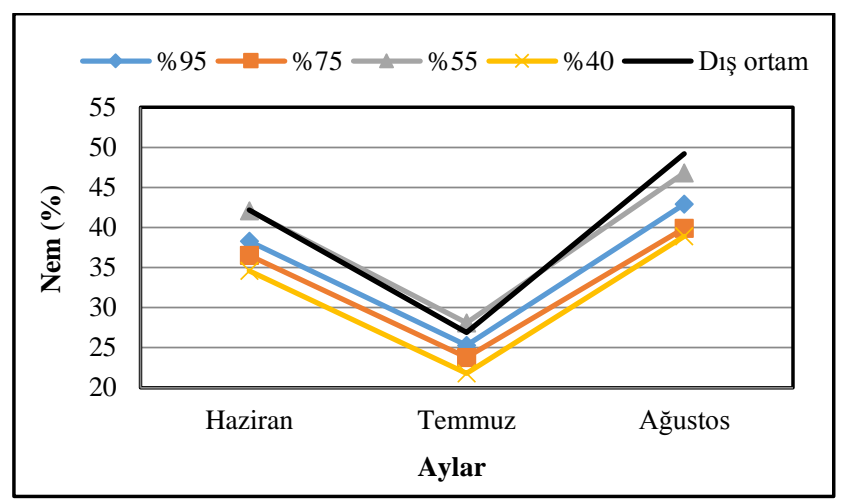

Şekil 7. Farklı gölgeleme oranlı ağların iç ve dış ortam aylık ortalama minimum nem değerleri.

Figure 7. Monthly inside and outside average minumum relative humidities values for different shading ratio nets.

Çizelge 3'de görüldüğü gibi farklı renkli ışı seçici ağların bitki vejetatif gelişim parametrelerinden bitki boy ve yaprak sayısı üzerine etkisi istatistiksel anlamda önemli çıkmamıştır. Ancak kök boğaz kalınlığı üzerine etkisi \% 5 düzeyinde anlamlı bulunmuştur. Duncan testi sonucunda üç farklı kök boğaz kalınlık grubu oluşmuştur. En fazla kök boğaz kalınlığı kontrol $(21.4 \mathrm{~mm})$ ve \% 40'llk yeşil ağ $(19.3 \mathrm{~mm})$ grubunda belirlenirken, en düşük kök boğaz kalınlığ $\% 95$ 'lik yeşil ağ grubunda $(14.7 \mathrm{~mm})$ elde edilmiştir. Çalışmada verim değerleri de istatistiksel anlamda \% 5 düzeyinde anlamlı bulunmuştur. Duncan testi sonucunda beş farklı grup oluşmuştur. En yüksek verim \% 40'lık yeşil ağ grubundan $\left(141.4 \mathrm{t} \mathrm{ha}^{-1}\right)$ en düşük verim değeri ise \% 95'lik yeşil ağ grubundan (43.8 $\left.\mathrm{tha}^{-1}\right)$ elde edilmiştir. Işık seçici ağların bazı meyve kalite parametreleri (ortalama meyve ağırlığı, meyve çapı, SÇKM, meyve suyunda $\mathrm{EC}-\mathrm{pH})$ üzerine etkisi de istatistiksel anlamda $\% 5$ düzeyinde anlamlı bulunmuştur. Duncan testi sonucunda; ortalama meyve ağırlığı bakımından dört, meyve çapı, SÇKM ve meyve suyunda EC parametreleri bakımından beş, meyve suyunda $\mathrm{pH}$ bakımından ise üç farklı grup oluşmuştur. En fazla meyve ağırlığı \% 40’lık yeşil ağ grubunda (88.4 gr) en az meyve

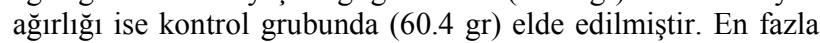
meyve çapı \% 40'lık yeşil ağ (49.9 mm) grubunda bulunmuşken en az meyve çapı \% 95'lik yeşil ağ grubundan $(44.6 \mathrm{~mm})$ elde edilmiştir. En fazla SÇKM kontrol grubunda (\% 5.2) en az SÇKM \% 95'lik yeşil ağ grubundan (\% 3.3) elde edilmiştir. En fazla meyve suyunda EC değeri \% 75'lik yeşil ağ $\left(6.0 \mathrm{dS} \mathrm{m}^{-1}\right)$ grubunda bulunmuşken en az EC değeri \% 55'lik yeşil ağ grubundan $\left(4.8 \mathrm{dS} \mathrm{m}^{-1}\right)$ elde edilmiştir. Çalışmada en fazla meyve suyunda $\mathrm{pH}$ değeri kontrol grubundan (4.6) en az $\mathrm{pH}$ değeri \% 75'lik ve \% 95'lik yeşil ağ gruplarından (4.3) elde edilmiştir.

\section{Sonuç}

$\mathrm{Bu}$ çalışma ile farklı gölgeleme oranlarına sahip yeşil renkli gölgeleme ağlarının dış ortam koşullarına göre ağ altına ulaşan toplam 1şınımı ve PAR 1şınımı azalttığ1 belirlenmiştir. Çalışmada \% 40'lık gölgeleme oranına sahip yeşil ağın en yüksek toplam 1şınım ve PAR geçirgenliğini gösterdiği saptanmıştır. Bununla birlikte anılan ağda gözlemlenen ve belirlenen bitki, meyve gelişimi ve verimin de daha iyi olduğu dikkate alındığında Antalya ekolojik koşullarında domates bitkisi için yeşil renkte en uygun gölgeleme oranının anılan ağ olduğu söylenebilir. Ayrıca çalışmadan \% 95'lik gölgeleme oranlı ağların ise bitkisel üretim açısından uygun olmayacağı belirlenmiştir. Araştırmada gölgeleme ağlarının ortam mikrokliması üzerine etkisi incelendiğinde netler altında ortam mikroklimasının birbirine benzer değişim gösterdiği ve dış ortam koşullarına göre biraz düşük değerler verdiği saptanmıştır. Ancak çalışma esnasında dış ortama göre netler altında daha stressiz bir çevre (direk güneş radyasyonunun engellenmesi ile) oluştuğu söylenebilir.

\section{Teşekkür}

Bu çalışmada gölgeleme ağları ve sulama sisteminin temininde Toros Sulama ve Drenaj Sist. Ltd. Şti. destek vermiştir. 


\section{Kaynaklar}

Abdrabbo MAA, Farag AA, Hassanein MK, Abou-Hadid AF (2010) Water consumption of eggplant under different microclimates. J. BioL Chem. Environ. Sci. 5(3): 239-255.

Arthurs SP, Stamps RH, Giglia FF (2013) Environmental modification inside photoselective shadehouses. Hort. Science 48(8): 975-979.

Barroso MR, Meneses JF, Mexia JT (1999) Comparison between greenhouse type, and their effects on two lettuce cultivars yield, and botrytis incidence. Acta Horticulturae 491: 137-142.

Briassoulis D, Mistriotis A, Eleftherakis D (2007) Mechanical behaviour and properties of agricultural nets. Part II: Analysis of the performance of the main categories of agricultural nets. Polymer Testing 26: 970-984.

Castellano S, Candura A, Scarascia Mugnozza G (2005) Relationship between solidity ratio, colour and shading effect of agricultural nets. Acta Horticulturae 801: 253-258.

Castellano S, Scarascia Mugnozza G, Russo G, Briassoulis D, Mistriotis A, Hemming S, Waaijenberg D (2008) Plastic nets in agriculture: A general review of types and applications. Applied Engineering in Agriculture 801: 253-258.

Castronuovo D, Statuto D, Muro N, Picuno P, Candido V (2015) Tecnical and agronomic behaviour of plastic nets for the greenhouse cultivation of sweet pepper in the mediterranean area. International Syposium on New Tecnologies and Management for Greenhouses, July of 19-23, Evora, Portekiz.

Cemek B, Demir Y (2005) Testing of the condensation characteristics and light transmissions of different plastic film covering materials. Polymer Testing 24(3): 269-404.

Doorenbos J, Pruitt WO (1977) Guidelines for Predicting Crop Water Requirements. Irrigation and Drainage paper 24, FAO, Rome.

Doorenbos J, Kassam AH (1979) Yield response to water. FAO, Irrigation and Drainage Paper No. 33, pp. 193.

Geoola F, Peiper UM, Geoola F (1994) Outdoor Testing of the Condensation Characteristics of Plastic Film Covering Materials Using a Model Greenhouse. Journal of Agricultural Engineering Research 57(3): 167-172.

Geoola F, Kashti Y, Peiper UM (1998) A model greenhouse for testing the role of condensation, dust and dirt on the solar radiation transmissivity of greenhouse cladding materials. Journal of Agricultural Engineering Research 71: 339-346.

Geoola F, Kashti Y, Levi A, Brickman R (2004) Quality evaluation of anti-drop properties of greenhouse cladding materials. Polymer Testing 23: 755-761.

Ilic Z, Milenkovic L, Durovka M, Kapoulas N (2011) The effect of color shade nets on the greenhouse climate and pepper yield, 46th Croatian and 6th International Symposium on Agriculture, Opatija, Croatia.
Ilic ZS, Milenkovic L, Sunic L, Barac S, Mastilovic J, Kevresan Z, Fallik E (2017) Effect of shading by coloured nets on yield and fruit quality of sweet pepper. Zemdirbyste-Agriculture 104(1): 53-62.

Justen VL, Fritz VA, Cohen JD (2012) Seasonal variation in glucosinolate accumulation in turnips grown under photoselective nettings. Horticulture Environment and Biotechnology 53(2): 108115.

Kırda C, Cetin M, Dasgan Y, Topcu S, Kaman H, Ekici B, Derici MR, Ozguven AI (2004). Yield response of greenhouse grown tomato to partial root drying and conventional deficit irrigation. Agr. Water Manage. 69: 191-201.

Kittas C, Baille A, Giaglaras P (1999) Influence of covering material and shading on the spectral distribution of light in greenhouses. Journal of Agricultural Engineering Research 73: 341-351.

Kittas C, Tchamitchian M, Katsoulas N, Karaiskou P, Papaioannou Ch. (2006) Effect of two UV absorbing greenhouse covering films on growth and yield of an eggplant soilless crop. Scientia Horticulturae 110: 30-37.

Kittas C, Rigakis MK (2009) Influence of Shading Screens on Microclimate, Growth and Productivity of Tomato. Acta Horticulturae 807(1): 97-102.

Nangare DD, Singh J, Meena VS, Bhushan B, Bhatnagar PR (2015) Effect of green shade nets on yield and quality of tomato (Lycopersicon esculentum Mill) in semi-arid region of Punjab. Asian Journal of Advances in Basic and Applied Science 1(1): 1-8.

Nemera DB, Zur N, Lukyanov V, Shlizerman L, Ratner K, Shahak Y, Cohen S, Sadka A (2015) Top photoselective netting results in improved microclimate, productivity, physiological performance and water-use efficiency in citrus. International Syposium on New Tecnologies and Management for Greenhouses, July of 19-23, Evora, Portekiz.

Schettini E (2011) Nets For Peach Protected Cultivation. J. of Ag. Eng. Eng. 4: 25-31.

Shahak Y, Gussakovsky EE, Gal E, Ganelevin R (2004) Color Nets: Crop protection and Light Quality Manipulation in One Technology. Acta Horticulturae 659: 143-151.

Shahak Y (2008) Photo selective Netting for Improved Performance of Horticultural Crops. A Review of Ornamental and Vegetable Studies Carried in Israel. Acta Horticulturae 770: 161-168.

Teitel M, Liron O, Haim Y, Seginer I (2008) Flow Through Inclined and Concertina-Shape Screens. Acta Horticulturae 801: 99-106. 